\title{
Pengaruh Model Pembelajaran Berbasis Masalah dan Investigasi Kelompok Terhadap Kemampuan Berpikir Kritis Materi Keanekaragaman Hayati Siswa SA Budisatrya Medan
}

\author{
Putri Wulan, Hasruddin, Tumiur Gultom \\ Program Studi Pendidikan Biologi, Program Pascasarjana, Universitas Negeri Medan, \\ 20221, Sumatera Utara Indonesia \\ E-mail: putriw05@gmail.com
}

\begin{abstract}
Abstrak
Penelitian ini dilakukan di kelas X SMA Budisatrya yang bertujuan untuk mengetahui pengaruh pengaruh model (Problem Based Learning, Group Investigation, dan Konvensional) terhadap kemampuan berpikir kritis siswa terhadap keanekaragaman hayati (flora) kelas X SMA Budisatrya Medan. Populasi dalam penelitian ini adalah 4 kelas, dan sampel yang digunakan dalam penelitian ini terdiri dari tiga kelas, kelas model $\mathrm{X} 2$ berfungsi sebagai kelas eksperimen yang diajar oleh Problem Based Learning, kelas X3 digunakan sebagai kelas eksperimen yang diajarkan oleh Model Group Investigation, dan Kelas X1 yang digunakan sebagai kelas kontrol diajarkan dengan model konvensional. Alat pengumpulan data menggunakan: menguji kemampuan berpikir kritis dalam bentuk pilihan ganda adalah 25 pertanyaan. Metode penelitian ini quasi eksperimen dengan teknik analisis data menggunakan Anacova dengan tingkat signifikansi $\alpha=0,05$ dan dilanjutkan dengan uji Scheff dengan SPSS 22.0. Hasil penelitian menunjukkan bahwa: ada pengaruh model pembelajaran (Problem Based Learning, Group Investigation and Conventional) terhadap kemampuan berpikir kritis siswa. Kemampuan berpikir kritis siswa yang belajar dengan model Problem Based Learning 81,60 \pm 7,72 lebih tinggi dan berbeda secara signifikan dari model Investigasi Kelompok 74,56 \pm 8,92 dan Konvensional 61,47 $\pm 11,26$.
\end{abstract}

Kata kunci: Pembelajaran Berbasis Masalah, Investigasi Kelompok, Keterampilan Memecahkan Masalah, Keterampilan Berpikir Kritis.

\section{Abstract}

This research was conducted in class X SMA Budisatrya field that aims to determine: the effect influence model (Problem Based Learning, Group Investigation, and Conventional) towards critical thinking skill of students on material biodiversity (flora) class X SMA Budisatrya Medan. The population in this study are 4 classes, and samples used in this study consisted of three classes, model class $X_{2}$ serve as an experimental class taught by Problem Based Learning, class $X_{3}$ be used as an experimental class taught by the model Group Investigation, and class $X_{1}$ used as a control class is taught by conventional model. Data collection instruments using: test the critical thinking skill in the form of multiple choice is 25 question. This research method quasi experiment with data analysis techniques using Anacova with significance level $\alpha=0.05$ and followed by Scheff's test with SPSS 22.0. The result showed that: there is the effect of the learning model (Problem Based Learning, Group Investigation and Conventional) against the student's critical thinking skills. Critical thinking skills of students that learned with Problem Based Learning model of $81.60 \pm 7.72$ higher and significantly different than Group Investigation model $74.56 \pm 8.92$ and Conventional $61.47 \pm 11.26$. 
Keywords: Problem Based Learning, Group Investigation, Problem Solving Skills, Critical Thinking Skills

\section{A. PENDAHULUAN}

Sejauh ini proses pembelajaran di sekolah masih didominasi oleh sebuah paradigma yang menyatakan bahwa sebuah pengetahuan (knowledge) merupakan perangkat fakta-fakta yang harus dihafal. Proses pembelajaran masih cenderung berpusat pada guru, sehingga siswa menjadi kurang aktif dalam proses pembelajaran biologi. Selain itu, pembelajaran biologi masih berpusat pada hasil belajar pada tingkat kognitif siswa yang masih rendah (Kunandar, 2007)

Jika diamati secara cermat maka masalah-masalah yang ditemukan di lapangan dapat dikategorisasikan ke dalam dua faktor yaitu yang berasal dari dalam (internal) siswa itu sendiri dan faktor-faktor yang berasal dari luar (eksternal) siswa. Suparno (2001) mengemukakan bahwa salah satu faktor dari dalam diri siswa adalah mereka merasa sukar mencerna pelajaran biologi karena materinya dianggap sulit. Mereka menganggap pelajaran biologi adalah pelajaran banyak menghafal (Huda, 2002).

Berdasarkan observasi yang telah dilakukan di SMA Budisatrya Medan, rendahnya hasil belajar biologi khususnya materi Keanekaragaman Hayati bisa diakibatkan oleh model pembelajaran yang kurang menarik sehingga siswa lebih dahulu merasa jenuh sebelum mempelajari materi yang diberikan oleh guru biologi. Guru biologi masih mendominasi kegiatan belajar mengajar di kelas dan menjadi satu-satunya sumber informasi sehingga kegiatan pembelajaran hanya mengutamakan aspek kognitif tanpa memperhatikan aspek afektif dan psikomotorik. Pada kegiatan belajar mengajar biologi pada materi Keanekaragaman Hayati, guru biologi masih menggunakan metode ceramah dan diskusi.

Selain itu, kegiatan pembelajaran didalam kelas siswa tidak mengasah kemampuan berpikir kritis siswa. Hal itu ditandai dengan minimnya aktivitas bertanya, menjawab, menanggapi dan mengemukakan pendapat, belum terbiasa belajar dengan diawali permasalahan-permasalahan dan menemukan sendiri apa yang mereka pelajari, sehingga kemampuan berpikir kritis siswa tidak dapat dimanfaatkan secara maksimal.

Menurut Muhfahroyin (2009) berpikir kritis adalah proses yang melibatkan operasi mental seperti induksi, deduksi, klasifikasi, dan penalaran. Kunci berpikir kritis adalah mengembangkan pendekatan impersonal yang memperhatikan argumentasi dan fakta sejalan dengan pandangan, pendapat dan perasaan personal. Ennis dalam Costa (2001), menyebutkan ada lima aspek berpikir kritis, yaitu: a) memberi penjelasan dasar (klarifikasi), b) membangun keterampilan dasar, c) menyimpulkan, d) memberi penjelasan lanjut, dan e) mengatur strategi dan taktik.

Sedangkan Hassoubah (2007), menyebutkan bahwa keterampilan berpikir kritis adalah keterampilan untuk: 1) menentukan kredibilitas suatu sumber; 2) membedakan antara yang relevan dari yang tidak relevan; 3) membedakan fakta dari penilaian; 4) mengidentifikasi dan mengevaluasi asumsi yang tidak terucapkan; 5) mengidentifikasi bias yang ada; 6) mengidentifikasi sudut pandang; dan 7) mengevaluasi bukti yang ditawarkan untuk mendukung pengakuan.

Berdasarkan hal tersebut di atas, berpikir kritis adalah keterampilan berpikir tingkat tinggi yang berpotensi meningkatkan daya analitis kritis siswa. Peningkatan daya analitis kritis siswa sangat berkaitan dengan peningkatan kemampuan intelektual siswa. Oleh karena itu, menumbuhkembangkan keterampilan berpikir kritis siswa dalam pembelajaran merupakan upaya untuk meningkatkan hasil belajar siswa. 
Agar proses pembelajaran dapat berjalan secara optimal dan hasil belajar yang memuaskan, perlu rencana pemilihan model pembelajaran yang tepat. Salah satu alternatif pembelajaran yang dapat meningkatkan kemampuan berpikir kritis siswa dalam pembelajaran biologi khususnya materi Keanekaragaman Hayati adalah pembelajaran yang memberikan ruang kepada siswa untuk bisa menemukan dan membangun konsep sendiri dan dapat mengembangkan kemampuan berpikir kritis siswa. Model pembelajaran yang dapat diterapkan adalah Pembelajaran Berbasis Masalah (PBM) dan Investigasi Kelompok (IK) yang sangat cocok diterapkan pada materi Keanekaragaman Hayati yang merupakan materi yang membutuhkan banyak penyelidikan dan banyak masalah yang harus dipecahkan berkaitan dengan kehidupan sehari-hari siswa.

Menurut Ratnaningsih (2003), Problem Based Learning (PBL), merupakan salah satu model pembelajaran pembelajaran yang menuntut aktivitas mental siswa untuk memahami suatu konsep pembelajaran melalui situasi dan masalah yang disajikan pada awal pembelajaran dengan tujuan untuk melatih siswa menyelesaikan masalah. Menurut Arends (2004), model PBL merupakan suatu model pembelajaran yang menuntun peserta didik mengerjakan permasalahan yang autentik dengan maksud untuk menyusun pengetahuan mereka sendiri, mengembangkan inkuiri dan keterampilan berpikir tingkat tinggi, mengembangkan kemandirian dan percaya diri.

Barrows (1996) dalam karyanya yang berjudul "Problem-Based Learning in Medicine and Beyond: A Brief Overview" mengemukakan beberapa karakteristik Problem-Based Learning sebagai berikut. 1) proses pembelajaran bersifat studentcentered, 2) proses pembelajaran berlangsung pada kelompok kecil, 3) guru berperan sebagai fasilitator atau pembimbing, 4) permasalahan-permasalahan yang disajikan merupakan stimulus pembelajaran, 5) informasi baru diperoleh dari belajar secara mandiri (self- directed learning), dan 6) masalah merupakan wahana untuk mengembangkan keterampilan pemecahan masalah. Sementara itu, Ehlert (2004) menyatakan bahwa keuntungan model PBL adalah: (1) menyediakan kesempatan kepada peserta didik untuk melakukan penelitian; (2) membangun keterampilan berpikir kritis; (3) mengenal content materi subyek dan membangun tujuan sesuai konsep; (4) memberdayakan peserta didik menjadi seseorang ahli dalam bidang tertentu; (5) memungkinkan peserta didik menghasilkan lebih dari satu bentuk solusi; (6) menyatakan ketidaktentuan dan kebutuhan untuk mengembangkan asumsi; dan (7) memotivasi peserta didik belajar.

Seperti halnnya PBL, pembelajaran kooperatif tipe Investigasi Kelompok (IK) merupakan model pembelajaran yang sesuai dengan paradigma konstruktivis. Model IK memberikan kesempatan seluas-luasnya kepada siswa untuk terlibat langsung dan aktif dalam proses pembelajaran mulai dari perencanaan sampai cara mempelajari suatu topik (Suati, 2010). Melalui model IK pebelajar berinteraksi dengan banyak informasi sambil bekerja secara kolaboratif dengan lainnya dalam situasi kooperatif untuk menyelidiki permasalahan, perencanaan dan melakukan presentasi, dan mengevalusi hasil pekerjaan mereka (Tsoi, dkk, 2004). Model ini juga menuntut siswa untuk memiliki kemampuan yang baik dalam berkomunikasi maupun keterampilan proses kelompok (group process skills). Melalui model GI suasana belajar akan lebih efektif, kerjasama kelompok dalam pembelajaran akan membangkitkan semangat siswa untuk memiliki keberanian dalam mengemukan pendapat dan berbagi informasi dengan teman lainnya dalam membahas materi pembelajaran (Mashita, dkk, 2012).

Setting pembelajaran dengan model PBM dan IK dilaksanakan dalam kelompokkelompok kecil sehingga selama proses pembelajaran memberi peluang bagi siswa untuk berhadapan dengan kompleksitas pendapat dari teman-teman sekelompoknya. Keadaan 
ini membiasakan siswa untuk cepat dan tepat dalam mengambil keputusan. Hal ini mengandung pengertian bahwa siswa sebagai pebelajar harus aktif sendiri mengkonstruksi pengetahuan yang dipelajari sehingga konsep yang dipelajari tertanam pada struktur kognitifnya dan mampu mengaitkan antara satu konsep dengan konsep lainnya. Jadi, jelas model PBM dan IK menyediakan peluang bagi siswa untuk menguatkan pemahaman konsep yang dimiliki (Akcay, 2009).

Kelebihan model IK dalam meningkatkan hasil belajar adalah dapat membantu siswa memahami konsep-konsep yang sulit. Keunggulan dari kelompok ini adalah siswa lebih mampu dalam mengungkapkan alasan secara logis atas pilihan jawaban yang mereka pilih saat dilakukan evaluasi. Hal ini menunjukkan para peserta didik harus mempunyai keingintahuan untuk memahami materi dengan banyak berpikir agar peserta didik dapat melakukan tutor sebaya. Strategi pembelajaran kooperatif dapat menambah motivasi dan meningkatkan prestasi akademik (Sanjaya, 2008).

\section{B. METODE PENELITIAN}

Penelitian ini dilaksanakan di Yayasan Perguruan Budisatrya Medan, yang beralamat Jalan Letda Sujono No. 166, Bandar Selamat, Medan Tembung, Medan 20223, Sumatera Utara. Populasi dalam penelitian ini adalah seluruh siswa kelas X SMA Budisatrya Medan sebanyak 4 kelas yang berjumlah 157 siswa Tahun Pembelajaran 2016/2017. Pengambilan sampel dilakukan secara random sampling. Sampel yang digunakan dalam penelitian ini terdiri dari tiga kelas yaitu kelas $\mathrm{X}_{2}$ dijadikan sebagai kelas eksperimen yang diajarkan dengan Model Pembelajaran Berbasis Masalah (PBM), kelas $\mathrm{X}_{3}$ dijadikan sebagai kelas eksperimen yang diajarkan dengan model Investigasi Kelompok (IK), dan kelas $\mathrm{X}_{1}$ dijadikan kelas kontrol yang diajarkan dengan model Konvensional. Ketiga kelompok tersebut diberikan tes awal kemampuan berpikir kritis (pretes). Setelah diberi perlakuan, kemudian seluruh kelompok diberikan postes untuk mengukur kemampuan berpikir kritis siswa.

Instrumen yang digunakan untuk mengukur kemampuan berpikir kritis berupa soal pilihan ganda sebanyak 25 soal, yang disusun berdasarkan ranah taksonomi Bloom (C4-C6).

Data hasil penelitian diolah dan dianalisis secara bertahap. Hipotesis diuji dengan menggunakan rumus Analisis Covarian (Anacova) pada taraf signifkansi $\alpha=0,05$. Ha (terdapat pengaruh) diterima

apabila nilai signifikansi < 0,05 dan sebaliknya. Apabila hasil uji statistik menunjukkan adanya pengaruh maka analisis dilanjutkan dengan uji Scheff. Pengolahan data dilakukan dengan menggunakan software SPSS 22.0.

\section{HASIL DAN PEMBAHASAN}

\section{Hasil}

Ringkasan data hasil penelitian Kemampuan Berpikir Kritis (KBK) siswa disajikan dalam Tabel 1.1. berikut ini: 
Tabel 1.1 Deskripsi KBK Siswa

\begin{tabular}{cccccccccc}
\hline Kelas & Pr & Pr & Po & Po & \multicolumn{2}{c}{ Mean } & \multicolumn{2}{c}{ Std. Dev } \\
\cline { 6 - 9 } & Tr & Tt & Tr & Tt & Pr & Po & Pr & Po \\
\hline \multirow{2}{*}{ PBM } & 28 & 84 & 68 & 96 & 57,60 & 81,60 & 12,38 & 7,72 \\
IK & 12 & 80 & 52 & 96 & 54,36 & 78,21 & 15,38 & 8,92 \\
Konv & 12 & 80 & 44 & 92 & 48,00 & 74,68 & 15,59 & 11,26
\end{tabular}

\section{Keterangan:}

PBM = Pembelajaran Berbasis Masalah

IK = Investigasi Kelompok

Konv $=$ Konvensional

$\operatorname{Pr} \quad=$ Pretes

Po $=$ Postes

$\operatorname{PrTr}=$ Nilai kemampuan berpikir kritis pretes terendah

PrTt = Nilai kemampuan berpikir kritis pretes tertinggi

PoTr = Nilai kemampuan berpikir kritis postes terendah

PoTt = Nilai kemampuan berpikir kritis postes tertinggi

a. Pengaruh Model Pembelajaran terhadap Kemampuan Berpikir Kritis Siswa

Hasil analisis kovarian (Anacova) dengan bantuan SPSS for windows 22,0 menunjukkan bahwa model pembelajaran berpengaruh secara signifikan terhadap kemampuan berpikir kritis siswa $(\mathrm{F}=43,79 ; \mathrm{P}=0,00)$ dengan skor pretes sebagai kovariant berpengaruh terhadap nilai postes $(\mathrm{F}=6660,48 ; \mathrm{P}=0,00)$. Selanjutnya hasil Uji Scheffe menunjukkan bahwa kemampuan berpikir kritis siswa yang dibelajarkan dengan model pembelajaran PBM 81,60 \pm 7,72 lebih tinggi secara signifikan dibandingkan dengan model pembelajaran IK 74,56 \pm 8,92 dan Konvensional 61,47 \pm 11,26 sebagai berikut.

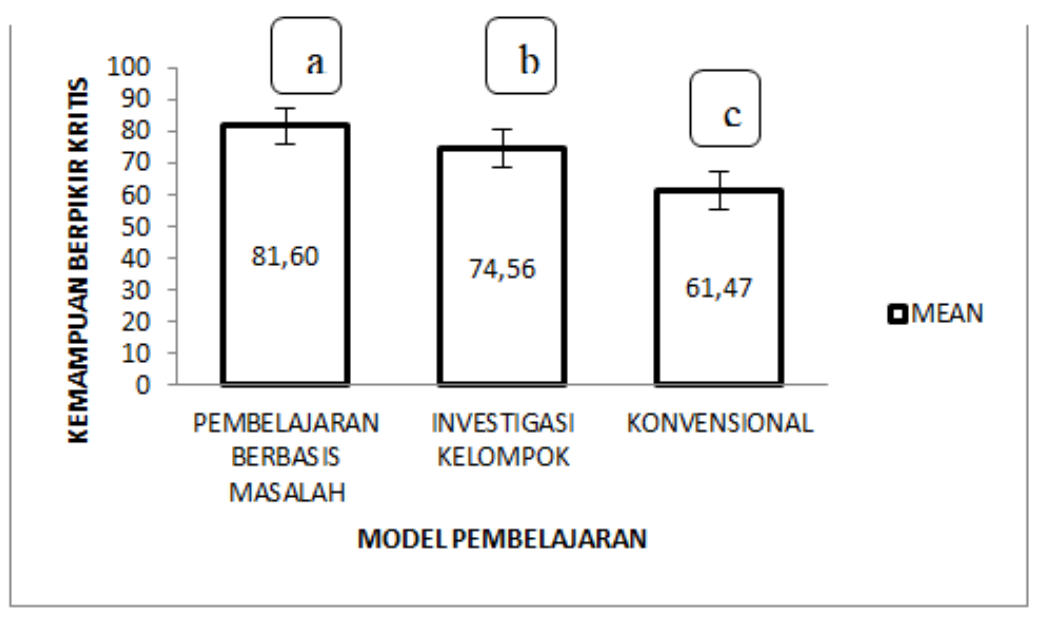

Gambar 1. Pengaruh Model Pembelajaran terhadap Kemampuan Berpikir Kritis Siswa 
Materi Keanekaragaman Hayati (Tanaman) Tingkat Jenis Siswa Kelas X SMA Budisatrya Medan. Huruf yang berbeda pada gambar diatas berarti berbeda signifikan (Uji Scheffe).

Berdasarkan hasil postes diperoleh skor kemampuan berpikir kritis siswa pada materi keanekaragaman hayati (tanaman) tingkat jenis berdasarkan indikator kemampuan berpikir kritis, dapat dilihat sebagai berikut:

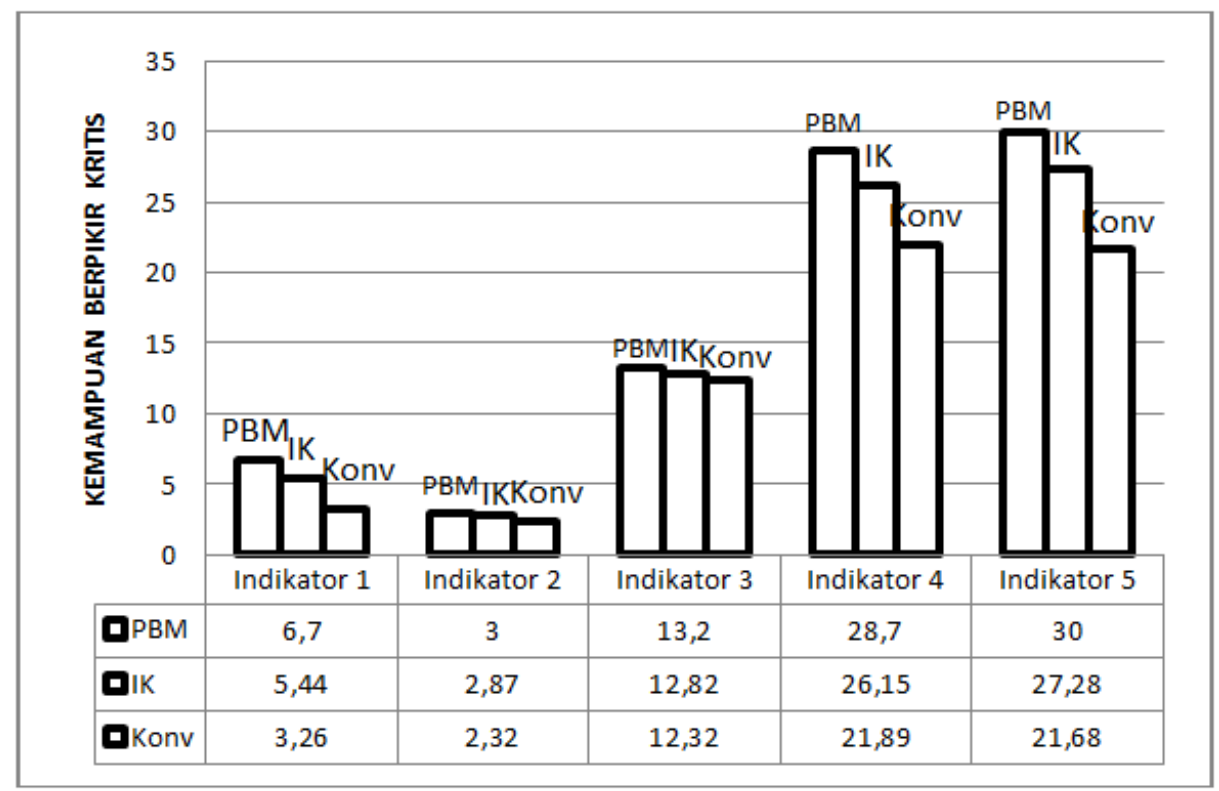

Gambar 2. Kemampuan Siswa Menjawab Tes Kemampuan Berpikir Kritis Materi Keanekaragaman Hayati (Tanaman) Tingkat Jenis Berdasarkan Indikator Kemampuan Berpikir Kritis.

\section{Pembahasan}

b. Pengaruh Model Pembelajaran terhadap Kemampuan Pemecahan Masalah (KPM) Siswa

Pada hasil penelitian diperoleh bahwa terdapat pengaruh model pembelajaran terhadap kemampuan berpikir kritis siswa. Hal ini ditandai oleh rata-rata kemampuan berpikir kritis siswa yang dibelajarkan dengan model Pembelajaran Berbasis Masalah (PBM) berbeda signifikan dengan rata-rata kemampuan berpikir kritis siswa yang dibelajarkan dengan model Investigasi Kelompok (IK) dan Konvensional. Siswa yang dibelajarkan dengan model PBM memiliki rata-rata kemampuan berpikir kritis paling tinggi dibandingkan dengan model IK maupun Konvensional. Hal tersebut disebabkan oleh: (1) siswa dapat belajar dalam kelompok kecil dan heterogen; (2) siswa diajak menghadapi berbagai situasi kehidupan nyata yang menuntut jawaban yang tidak mudah; (3) siswa dapat menganalisis dan menetapkan masalah, mengembanngkan hipotesis dan membuat prediksi, mengumpulkan dan menganalisis informasi, melaksanakan eksperimen, membuat inferensi dan menarik kesimpulan (Arends, 2008).

Pada pembelajaran berbasis masalah, siswa dibimbing untuk berpikir secara ilmiah yang dilakukan secara sistematis dan empiris. Sistematis artinya berpikir ilmiah dilakukan melalui tahapan-tahapan tertentu dengan menggunakan metode ilmiah, 
sedangkan empiris artinya proses penyelesaian masalah didasarkan pada data dan fakta yang jelas. Pembelajaran yang diatur sedemikian rupa mampu menunjukkan kemampuan berpikir kritis yang baik karena pengkonstruksian pengetahuan dilakukan bersama kelompok yang memungkinkan masing-masing siswa mengungkapkan pendapat, mendengarkan pendapat teman sekelompok, dan secara bersama-sama membangun pengertian. Pembelajaran berkembang jika peserta didik berpartisipasi aktif dalam proses pembelajaran tersebut. Dengan demikian proses pembelajaran bukan lagi sekedar mentransfer ilmu dari guru ke siswa, tetapi juga merupakan proses pemerolehan konsep yang berorientasi pada keterlibatan siswa secara aktif dan langsung.

Kemudian untuk rata-rata kemampuan berpikir kritis siswa yang dibelajarkan dengan model konvenional paling rendah dibandingkan dengan model pembelajaran PBM maupun GI. Hal tersebut disebabkan oleh penggunaan model Konvensional yang masih sederhana. Kegiatan pembelajaran ini berpusat pada guru sebagai penceramah dan komunikasi terjadi searah. Sebab model yang digunakan akan memaksimalkan pembelajaran asal sesuai dengan materi, alokasi waktu dan fasilitas sekolah. Dalam pembelajaran konvensional, siswa dipandang sebagai subjek yang belum mengetahui apa-apa dan hanya menerima ilmu pengetahuan dari guru. Maka kemampuan berpikir kritis siswa pun akan memberikan rata-rata yang rendah bila dibandingkan dengan pembelajaran model PBM maupun IK.

Hasil penelitian ini sesuai dengan penelitian yang dilakukan oleh Dewi, dkk (2012) yang menyatakan bahwa terdapat pengaruh positif dan signifikan model PBL melalui metode ekperimen terhadap kemampuan kognitif $\mathrm{C} 3, \mathrm{C} 4, \mathrm{C} 5$, dan $\mathrm{C} 6$ berdasarkan keterampilan berpikir kritis fisika. Dengan model PBL, aktivitas eksperimen siswa terhadap kemampuan kognitif siswa juga meningkat. Hasil penelitian ini juga sesuai dengan penelitian yang dilakukan oleh Suwondo (2010) yang menyatakan bahwa terdapat peningkatan hasil belajar setelah penerapan model pembelajaran PBL.

\section{KESIMPULAN}

Berdasarkan hasil penelitian dan pembahasan disimpulkan bahwa terdapat pengaruh model pembelajaran (Pembelajaran Berbasis Masalah, Investigasi Kelompok dan Konvensional) terhadap kemampuan berpikir kritis siswa. Kemampuan berpikir kritis siswa yang dibelajarkan dengan model PBM 81,60 \pm 7,72 lebih tinggi serta berbeda signifikan dibandingkan dengan model pembelajaran IK 74,56 \pm 8,92 dan Konvensional $61,47 \pm 11,26$. Dari data tersebut dapat disimpulkan bahwa model Pembelajaran Berbasis Masalah lebih baik daripada model Investigasi Kelompok dan Konvensional terhadap kemampuan berpikir kritis siswa pada materi keanekaragaman hayati (tanaman) pada tingkat jenis kelas X SMA Budisatrya Medan.

\section{E. DAFTAR RUJUKAN}

Akcay, B., 2009. Problem-Based Learning in Science Education. Journal of Turkish Science Education. 6 (1): 1-10.

Arends, R. I., 2004. Learning to Teach. (6thEd). McGraw-Hill, New York.

Barrows, H. S., 1996. Problem-Based Learning in Medicine and Beyond. New Direction for Teaching and Learning. Jossey: Bass Publishers.

Costa, A.L., 2001. Developing Minds: A Resource Book For Teaching Thinking (3rd ed).. ASCD, Virginia.

Dewi, L. R., Wiyatmo, Y., \& Ruwanto, B., 2012. Pengaruh Model Problem Based Learning (PBL) Melalui Metode Ekperimen terhadap Kemampuan Ranah Kognitif Berdasarkan Keterampilan Pemecahan Masalah Fisika pada Materi Sub Bahasan 
Asas Black untuk Siswa Kelas X SMA Negeri 1 Sewon Bantul Yogyakarta. Jurnal Cakrawala Pendidikan UNY. 1 (1): 1-8

Ehlert, M., 2004. An Evaluation of Problem-Based Learning: Application in an Undergraduated Supply Chain Management Course. Northwestern University.

Hassoubah, Z.I., 2007. Mengasah Pikiran Kreatif dan Kritis: Disertai Ilustrasi dan Latihan. Terjemahan Bambang Suryadi. Developing Creative \& Critical Thinking Skills: A Handbook for Students. Nuansa, Bandung.

Huda, N.. 2002. Strategi Pembelajaran, PT Multi Kreasi Satudelapan, Jakarta.

Kunandar, 2007. Guru Proffesional Implementasi Kurikulum Satuan Pendidikan (KTSP)

Sukses dalam Sertifikasi Guru. PT Raja Grafindo Persada, Jakarta.

Mashita, A., Sudomo, J., dan Widowati, A. (2012). Perbedaan Penerapan Model Problem Based Learning dan Cooperative Learning Tipe Group Investigation dalam Meningkatkan Keterampilan Observasi dan Kemampuan Kognitif Siswa pada Pembelajaran IPA Terpadu Tema Pencemaran Air. Jurnal Cakrawala Pendidikan UNY. 1 (1): 1-12

Muhfahroyin, 2009. Memberdayakan Kemampuan Berpikir Kritis. (Online). http://www.berpikir-kritis blogspot.com. (diakses 28 Oktober 2016).

Ratnaningsih, N., 2003. Pengembangan Kemampuan Berfikir Matematik Siswa SMU Melalui Pembelajaran Berbasis Masalah. Tesis. Program Pasca Sarjana UPI.

Sanjaya, W., 2008. Strategi Pembelajaran Standar Berorientasi Standar Proses. Jakarta: Predana Media Group.

Suati, N.N., 2010. Pengaruh Model Pembelajaran Berbasis Masalah dan Kooperatif Group Investigasi Terhadap Sikap ilmiah dan ketrampilan berpikir kritis Siswa Kelas X SMAN 1 Manggis Tahun Pelajaran 2010/2011. Jurnal Pendidikan dan Pengajaran Undiksha. 2 (2): 1-12.

Suparno, S., 2001. Membangun Kompetensi Belajar. Departemen Pendidikan Nasional, Jakarta.

Suwondo. 2010. Penerapan Model Problem Based Learning (PBL) untuk Meningkatkan Kemampuan Pemecahan Masalah pada Konsep Rancangan Eksperimen dalam Mata Kuliah Biometri. Jurnal Pendidikan UNRI.1 (1): 1-10

Tsoi, M.F., Ngoh, K. G., dan Lion, S.C. (2004). Using Group Investigation for Chemistry in Teacher Education. Asia Fasifik Forum on Science Learning and Teaching (Online). 5 (6): 51-63 